\title{
Risk Analysis and Management Strategies of Sugarcane Producer in Selecting Varieties: Failure Mode and Effect Analysis (FMEA) Approach
}

\author{
Ahmad Zainuddin ${ }^{1}$, Illia Seldon Magfiroh ${ }^{1}$, Intan Kartika Setyawati ${ }^{1}$, and Rena Yunita Rahman ${ }^{1}$ \\ ${ }^{1}$ Agribusiness Study Program, Faculty of Agriculture, University of Jember
}

\begin{abstract}
The composition of sugar cane varieties which planted are not balanced especially in the nursery sector that caused the efficiency of the sugar industry on national scale low. This condition happens because there are risks faced by farmers in determining the varieties of sugarcane that will be planted. The aim of this study was to analyze the risk of production and strategies to overcome the risks due to the selection of sugar cane varieties. Samples used in the study were 30 people (12 sugarcane farmers, 6 managers, and assistant plant managers, and 12 people from APTR / KPTR. Data were analyzed using the method of Failure Mode and Effect Analysis (FMEA). Research Results indicate that the risks classified as very high categories that can be caused by the selection of certain sugar cane varieties are production risk, sugar quality risk and sugar price-output risk Risk management that can be applied to reduce the risk due to variety selection is to use superior varieties, the development of new varieties which has high productivity, increase cultivation technology by farmers, and unloads ratoon after 2 times harvesting.
\end{abstract}

\section{INTRODUCTION}

Nowadays, national sugar consumption reaches 5.8 million tons, and it will increase to 6.6 million tons -7.0 million tons in the next 5 years. Direct consumption needs for household consumers are currently estimated at 3.0 million tons of sugar cane with white crystal (GKP) and the rest is consumption needs (indirect) for industries that are met from refined crystal sugar (GKR) [1]. In per capita counts, with a population of around 240 million, sugar consumption ranges from $22 \mathrm{~kg} /$ year, or slightly higher than the per capita consumption of the world community [2]. The high national sugar consumption is clearly a "homework" for the government, farmers, sugar factories, and all national sugar industry stakeholders.

Meanwhile, national sugar production is currently still not meeting its consumption needs. Indonesia's current sugar production is only around 2.69 million tons or 45 percent of the national sugar needs. Of the total sugar production, around 1.45 million tons are produced by sugar BUMN, and the remainder by BUMS (private) [1].
Faced with this situation, given that the national sugar industry is concerned with meeting the people's basic food

needs, the livelihoods of many people and the stability of the national economy, it becomes important to be dealt with as well as possible. For this reason, comprehensive steps in the form of direction, focus, strategies and policies are needed to ensure that the atmosphere of development of the national sugar industry is competitive, meeting the people's need as a sustainable, stable prices, adequate guarantees for the income of sugarcane farmers, right distribution and the development of sugar factories in the right direction and technology.

Sugar cane productivity target in the next 5 years is relatively high, as much as 93 tons/ha [1], [3]. The target can be achieved by the introduction of superior varieties, seed treatment, ratoon removal, and land management. New superior sugar cane varieties are used to replace sugar cane varieties that have been planted for more than 8 years. Varieties that are planted for more than 8 years can cause genetic degeneration which has implications for 
increased pest and disease attacks so that sugarcane productivity decreases. Actually, Pusat Penelitian Perkebunan Gula Indonesia (P3GI) has found superior seeds with a yield potential of up to 12 percent and land productivity reaching 113.1 tons/ha [3]. The superior sugar cane varieties are able to produce the performance that is far higher than the existing varieties.

The main problem in the nursery sector which caused sugar cane on national scale has low efficiency is the sugar cane varieties that planted not balance especially farmers who plant sugar cane with early, middle, and latematuring makes the yield does not optimal. In the field, in general, the composition of the late maturing variety is far more than other varieties. Farmers prefer certain types of varieties because farmers more believe and have superiority over other varieties.

In addition, the selection of certain varieties by farmers will have implications for the production of sugar cane produced. The application of new varieties will produce a different production than using varieties that have been trusted by farmers. This is certainly a risk that must be faced by sugarcane farmers. Production fluctuations will occur if farmers will use certain varieties. Therefore, research on strategies and risk management due to farmers' choice of varieties is important to study.

Researches on the risks and production management of sugarcane farming have been done including research by [2], [4], [13], [5]-[12]. These studies focus on increasing sugarcane productivity and the risk of sugarcane farming production, and only a few studies that concern on production risk. The novelty of this research is the risks analyzed include production risk, quality risk and income of farmers associated with the selection of sugar cane varieties and the end of the discussion discussed the risk management of sugarcane farming.

\section{METHOD}

This research had done in the working area of PT. Perkebuan Nusantara $X$. The selection of research locations had done intentionally (purposively) because of PT. Perkebunan Nusantara $X$ is a state-owned enterprise that the biggest benefits and sugar in East Java. The research had done in the Kediri region. Kediri Regency was chosen because it consisted of 3 sugar factories which had medium and large capacities (PG Ngadirejo, PG Pesantren Baru, and PG Meritjan). This research was conducted from June to October 2018.

The sample used in this study were 12 sugar cane farmers, plant managers and plant assistants from 3 Sugar Mills totaling 6 (each PG 2 people), and 12 people from the Association of farmer who has sugar cane with small scale and Cooperatives of small sugar cane farmers produced from 3 Sugar factories in Kediri. The number of respondents in the study was 30 people. The selection of this sample is done purposively by considering the unavailability of a sampling frame in the study area. The sample was chosen based on knowledge of sugarcane varieties, farmers selected who have been cultivating the three varieties of sugar cane, while the managers and assistant managers selected are plant managers and assistant managers.

In order to analyze the value of production risk and strategies to overcome the risk of selecting sugar cane varieties, the failure mode and effect analysis (FMEA) method are used. In the FMEA method, three parameters (severity, event, and detection) are used to think about each failure mode according to the assessment on a scale of 1-10. The severity rating is the seriousness of the failure effect due to losses. The level of occurrence is a problem or frequency issued by sugarcane varieties with 1 being the chance of at least the occurrence and 10 being the highest occurrence. The degree of deterioration is the inability to fix a failure or the problem from a failure that cannot be solved before.

According to [14] and [15], FMEA comparisons are performed using a risk priority number (RPN). The formula of RPN is multiplication between Severity (S), Occurrence (O), and Detection (D), such as:

$$
\mathrm{RPN}=\mathrm{S} \times \mathrm{O} \times \mathrm{D}
$$

Failure models with higher RPN values will be considered to have more important values and can give higher priority to corrective actions when compared to lower RPN values.

Based on [16], the risk management process that commonly occurs in a farm there are four main activities, namely:

1. Identification of risk. By identifying risks, an event or phenomenon that causes uncertainty can be identified. This risk identification aims to recognize the uncertainty that will occur so that it can be controlled.

2. Risk assessment. This activity can choose management actions that are appropriate to the risk factors identified based on farming conditions and situations.

3. Implementation and Decision of risk management actions. Management of risk can be done by avoiding risk, risk mitigation or elimination, risk transfer, and or risk absorption or collection.

4. Risk control. Risk factors must be identified and must be monitored to identify potential increases in likelihood and consequences and the possibility of new risk factors can emerge.

After knowing the scale of the risk, then determined management or strategy to minimize the risks that occur in sugarcane farming.

\section{RESULT AND DISCUSSION}

The respondents involved in this research were a total of 30 respondents consisted 12 sugar cane farmers, plant managers and plant assistants from 3 Sugar Mills totaling 6 (each PG 2 people), and 12 people from the Association of farmer. Farmers in Kediri have mostly cultivated three 
varieties of sugar cane (early ripe sugarcane, middle ripe sugarcane and final ripe sugarcane). Sugar cane farmers in Kediri mostly determine varieties based on their level of productivity, speed in harvesting and ease of cultivation. Sugarcane varieties chosen by farmers greatly determine the quality of sugar cane (yield, productivity and quality of the sugar produced).

Based on the results of the literature studies and Focus Group Discussion (FGD), as well as in-depth interviews with experts obtained a framework to identify risks due to the selection of sugar cane seed varieties (Figure 1). This structure consists of three clusters, namely:

1. The cluster of problems, namely problems arising from the selection of varieties and being a concern in choosing sugarcane varieties. As for the cluster of problems included, such as the problem of increasing sugarcane productivity, sugarcane quality problems, and farmers' income problems.

2. Risk clusters are alternative risks identified based on literature studies that can be caused by the selection of sugarcane varieties, namely the risk of seed prices, HPT risks, production risks, product quality risks, and product price risks

3. Actors cluster consisting of actors who play a role in sugarcane farming, namely farmers, sugar mills, Sugar Cane Research and Development Center and related governments.

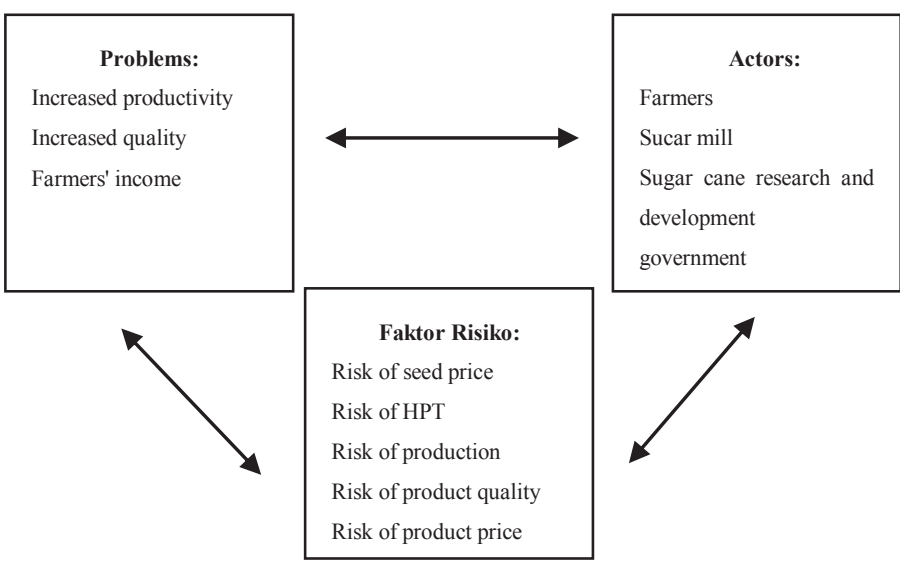

Figure 1. General Risk Assessment Framework Due to Selection of Sugar Cane Varieties.

According to [17], risk analysis is carried out to distinguish acceptable minor risks from major risks, as well as to provide data that will help the risk evaluation and control stage. The risk assessment stage in this study is assisted by the method of Failure Mode and Effect Analysis (FMEA). Three severity, occurrence, and detection components produce RPN (Risk Priority Numbers) values. The results of the risk assessment from expert opinion are seen in Table 1.

Risk evaluation using the FMEA method is done by comparing the level of risk calculated at the risk analysis stage with the standard criteria used. The RPN value is used to represent priorities for correction actions on a scale of 1-1000, which can be categorized into five classes of intervals which are described in the following table:

Table 1. Results of FMEA Analysis of Expert assessments

\begin{tabular}{|c|c|c|c|c|c|}
\hline $\begin{array}{c}\text { Risk } \\
\text { Factors }\end{array}$ & $\begin{array}{c}\text { Risk } \\
\text { Variable }\end{array}$ & $\begin{array}{c}\text { Severity } \\
(1-10)\end{array}$ & $\begin{array}{l}\text { Occurrenc } \\
\text { e (1-10) }\end{array}$ & $\begin{array}{l}\text { Detectio } \\
\text { n (1-10) }\end{array}$ & RPN \\
\hline \multirow[t]{3}{*}{$\begin{array}{l}\text { Risk of } \\
\text { seed } \\
\text { price }\end{array}$} & $\begin{array}{l}\text { Certain } \\
\text { seeds are } \\
\text { hard to get }\end{array}$ & 3 & 3 & 5 & 45 \\
\hline & $\begin{array}{l}\text { The price } \\
\text { of seeds is } \\
\text { relatively } \\
\text { expensive }\end{array}$ & 2 & 2 & 3 & 12 \\
\hline & \multicolumn{4}{|c|}{ Average } & 28,5 \\
\hline \multirow[t]{4}{*}{$\begin{array}{l}\text { Risk of } \\
\text { producti } \\
\text { on }\end{array}$} & $\begin{array}{l}\text { Low } \\
\text { productivi } \\
\text { tv }\end{array}$ & 7 & 7 & 6 & 294 \\
\hline & $\begin{array}{l}\text { Low } \\
\text { rendement }\end{array}$ & 7 & 8 & 7 & 392 \\
\hline & $\begin{array}{l}\text { Small rod } \\
\text { size }\end{array}$ & 5 & 4 & 5 & 100 \\
\hline & \multicolumn{4}{|c|}{ Average } & 262 \\
\hline \multirow[t]{4}{*}{$\begin{array}{l}\text { Risk of } \\
\text { product } \\
\text { quality }\end{array}$} & $\begin{array}{l}\text { Sugarcane } \\
\text { has low } \\
\text { ICUMSA }\end{array}$ & 6 & 6 & 6 & 216 \\
\hline & $\begin{array}{l}\text { Sweet, } \\
\text { clean and } \\
\text { fresh } \\
\text { criteria are } \\
\text { sometimes } \\
\text { not met }\end{array}$ & 5 & 6 & 8 & 240 \\
\hline & $\begin{array}{l}\text { The } \\
\text { quality of } \\
\text { sugarcane } \\
\text { varies }\end{array}$ & 7 & 7 & 5 & 245 \\
\hline & \multicolumn{4}{|c|}{ Average } & 234 \\
\hline \multirow{4}{*}{$\begin{array}{l}\text { Risk of } \\
\text { the } \\
\text { product } \\
\text { price }\end{array}$} & $\begin{array}{l}\text { The price } \\
\text { of sugar } \\
\text { fluctuates }\end{array}$ & 8 & 7 & 7 & 392 \\
\hline & Inflation & 4 & 5 & 5 & 100 \\
\hline & $\begin{array}{l}\text { Rupiah } \\
\text { exchange } \\
\text { rates and } \\
\text { bank } \\
\text { interest }\end{array}$ & 5 & 6 & 6 & 180 \\
\hline & \multicolumn{4}{|c|}{ Average } & 224 \\
\hline \multirow[t]{4}{*}{$\begin{array}{l}\text { Risk of } \\
\text { HPT }\end{array}$} & $\begin{array}{l}\text { Pests of } \\
\text { sugarcane } \\
\text { (uret) }\end{array}$ & 4 & 4 & 5 & 80 \\
\hline & $\begin{array}{l}\text { Sugarcane } \\
\text { disease }\end{array}$ & 4 & 4 & 4 & 64 \\
\hline & $\begin{array}{l}\text { Low of } \\
\text { sugarcane } \\
\text { treatment }\end{array}$ & 5 & 6 & 5 & 150 \\
\hline & \multicolumn{4}{|c|}{ Average } & 98 \\
\hline
\end{tabular}

Table 2. Risk Categories Based on RPN

\begin{tabular}{|c|c|c|}
\hline Value of RPN & $\begin{array}{c}\text { Risk } \\
\text { Category }\end{array}$ & Risk Control \\
\hline $1-50$ & Very low & Take \\
\hline
\end{tabular}




\begin{tabular}{|l|l|l|}
\hline $51-100$ & Low & Take \\
\hline $101-150$ & Middle & Averse \\
\hline $151-200$ & High & Mitigation \\
\hline $201-250$ (more than 250) & Very high & Mitigation \\
\hline
\end{tabular}

Source: [14]

Table 1 shows that the risk of sugarcane farming included in the very low risk is the risk of seed prices (average RPN 28.5). The price of sugar cane seeds is still relatively cheap, so farmers consider that the alternative selection of sugar cane varieties will have little impact on the risk of sugarcane seed prices. The risk of pests and diseases is also still relatively low, with an average RPN of 98. So far the seeds produced by farmers or those purchased by sugarcane farmers are very few which pose a risk of pests or diseases. The pests that often attack are uret caterpillar pests. These pests are not caused by the selection of seed varieties but can be caused by cultivation techniques that are not in accordance with Good Agricultural Practices (GAP) of sugarcane cultivation.

The risks that are classified as very high categories that can be caused by the selection of certain sugarcane varieties are production risk (average RPN of 262), sugarcane quality risk (average RPN of 234) and risk of sugarcane output prices (average RPN 224). The implications of selecting sugar cane seedlings are certainly the most influential in production. Certain sugar cane varieties will produce different yields from other varieties. Farmers stated that the varieties that were able to produce the highest productivity and high yield were Bulu Lawang (BL) varieties which were classified as late mature varieties. This statement is in accordance with the research of [10] who said that sugarcane farmers preferred Bulu Lawang (BL) varieties. This BL variety is relatively more resistant to pests and diseases and has a high level of productivity (can reach 1200 to 1500 quintal per hectare). This is different from the potential productivity of early and middle mature varieties that only range between 1000-1200 quintal per hectare.

Quality risk is also one of the implications of choosing certain varieties of sugar cane seeds. Certain varieties are able to produce sugarcane stems that are more same and when it is time to harvesting, sometimes productivity is still high and the stems produced are still the same. In addition to production and quality risks, the price risk is also measured. Price is one of the risks experienced by many sugarcane farmers. Price risk based on FMEA analysis is also a relatively high risk. This is linear with the research of [5], [6], [8], [18] which show that price risk is a risk often faced by small-scale farmers. While the risk of output prices is an implication of the uncertainty of sugar prices, inflation and the weakening of the exchange rate of the rupiah is also faced by farmers causing fluctuations in sugar prices.

Determination of appropriate actions to be taken in risk management resulting from the selection of sugarcane seed varieties in the results of the identification and evaluation of risks that have been carried out previously. Some of the risk control measures described in Table 3. are mitigation processes that can be carried out based on the greatest risk priority, namely production risk to farmers. The risk management that can be done, it shows in Table 3.

Table 3. Risk Management Due to Selection of Sugar Cane Seed Varieties

\begin{tabular}{|c|c|c|c|c|}
\hline No & Problems & Risk & $\begin{array}{l}\text { Managerial } \\
\text { Implication }\end{array}$ & Actor \\
\hline 1 & $\begin{array}{l}\text { Increased } \\
\text { sugarcane } \\
\text { productivity }\end{array}$ & $\begin{array}{l}\text { Production } \\
\text { and price } \\
\text { risk }\end{array}$ & $\begin{array}{l}\text { The use of } \\
\text { superior } \\
\text { varieties, the } \\
\text { development of } \\
\text { new varieties } \\
\text { that have high } \\
\text { productivity, } \\
\text { increased } \\
\text { mastery of } \\
\text { cultivation } \\
\text { technology, } \\
\text { uprooting } \\
\text { ratoon after } 2 \\
\text { times } \\
\text { harvesting }\end{array}$ & $\begin{array}{l}\text { Sugarcane } \\
\text { research and } \\
\text { development, } \\
\text { Farmers, } \\
\text { sugar mill, } \\
\text { KPTR }\end{array}$ \\
\hline 2 & $\begin{array}{l}\text { Product } \\
\text { quality } \\
\text { improvement }\end{array}$ & $\begin{array}{l}\text { Production } \\
\text { Quality Risk }\end{array}$ & $\begin{array}{l}\text { Guidance on } \\
\text { sugarcane } \\
\text { farmers to } \\
\text { implement } \\
\text { GAP, cutting } \\
\text { sugarcane at } \\
\text { optimum } \\
\text { maturity level, } \\
\text { supervision of } \\
\text { the application } \\
\text { of sugar cane } \\
\text { cultivation SOP } \\
\text { And the need } \\
\text { for assistance } \\
\text { from the sugar } \\
\text { mill }\end{array}$ & $\begin{array}{l}\text { Sugarcane } \\
\text { research and } \\
\text { development, } \\
\text { Farmers, } \\
\text { sugar mill, } \\
\text { KPTR }\end{array}$ \\
\hline 3 & $\begin{array}{l}\text { Increased } \\
\text { farmer income }\end{array}$ & $\begin{array}{l}\text { Product } \\
\text { price risk }\end{array}$ & $\begin{array}{l}\text { To increase the } \\
\text { price of } \\
\text { products need } \\
\text { government } \\
\text { policies that } \\
\text { support the } \\
\text { guarantee of } \\
\text { sugar prices and } \\
\text { the guarantee of } \\
\text { farmers' sugar } \\
\text { payments are } \\
\text { timely are } \\
\text { needed }\end{array}$ & $\begin{array}{l}\text { Sugarcane } \\
\text { research and } \\
\text { development, } \\
\text { Farmers, } \\
\text { sugar mill, } \\
\text { KPTR }\end{array}$ \\
\hline
\end{tabular}

Risk management that can be applied to reduce the risk due to the selection of varieties is to use superior varieties, the development of new varieties that have high productivity, increase mastery of cultivation technology by farmers, do ratoon unloading after 2 times harvesting, besides the need for guidance on sugarcane farmers to implement GAP of sugarcane cultivation, cutting down sugarcane at optimum maturity level, supervision of the application of sugar cane cultivation SOP and the need for 
assistance from the Sugar mill on the implementation of cultivation by farmers.

The role of farmers in reducing risk is to use superior varieties, increased mastery of cultivation technology, uprooting ratoon after 2 times harvesting, and apply GAP in accordance with the guidelines. While the role of manager and assistant manager is to guide sugarcane farmers to implement GAP, make an appeal to cut sugarcane at optimal maturity, supervise the application of sugar cane cultivation SOP and adjust the needs of sugar mills with farmers' yields.

\section{CONCLUSION}

The risks that are classified as very high categories that can be caused by the selection of certain sugarcane varieties are production risk (average RPN of 262), sugarcane quality risk (average RPN of 234) and risk of sugarcane output prices (average RPN 224). The implication of selecting sugarcane seedlings most influences the production and price of sugarcane.

Risk management that can be applied to reduce the risk due to the selection of varieties is to use superior varieties, the development of new varieties that have high productivity, increase mastery of cultivation technology by farmers, do ratoon unloading after 2 times harvesting, besides the need for guidance on sugarcane farmers to implement GAP of sugarcane cultivation, cutting down sugarcane at optimum maturity level, supervision of the application of sugar cane cultivation SOP and the need for assistance from the Sugar mill on the implementation of cultivation by farmers.

\section{REFERENCE}

[1] BUMN, National Sugar Cane Commodity Road Map. Jakarta: BUMN, 2018.

[2] A. A. Sulaiman, Y. Sulaeman, N. Mustikasari, D. Nursyamsi, and A. M. Syakir, "Increasing Sugar Production in Indonesia through Land Suitability Analysis and Sugar Mill Restructuring," Land, vol. 8, no. 1, pp. 1-17, 2019.

[3] Subiyono, Sumbangan Pemikiran Menggapai Kejayaan Industri Gula Nasional. Surabaya: PT. perkebunan Nusantara X, 2014.

[4] G. R. Patrick, P. H. Wilson, P. J. Barry, W. G. Bogges, and D. L. Young, "Risk Perceptions and Management Response: Producer-Generated Hypotheses for Risk Modelling," South. J. Agric. Econ., vol. 17, no. 2, pp. 231-238, 1985.

[5] T. Binici, A. A. KOC, C. Zulauf, and A. Bayaner, "Risk Attitudes of Farmers in Terms of Risk Aversion: A Case Study of Lower Seyhan Plain Farmers in Adana Province, Turkey," Turkish J. Agric. For., vol. 27, no. 1, pp. 305-312, 2003.

[6] O. Ayinde, O. Omotesho, and M. Adewumi,
"Risk Attitudes and Management Strategies of Small Scale Crop Producer in Kwara State, Nigeria: A Ranking Approach," African J. Bus. Manag., vol. 12, no. 2, pp. 217-221, 2008.

[7] R. Jain, S. Solomon, A. K. Shrivastava, and A. Chandra, "Sugarcane bud chips: A promising seed material," Sugar Tech, vol. 12, no. 1, pp. 6769, 2010.

[8] A. Guttormsen and K. Roll, "Production risk in subsistence agriculture," J. Agric. Educ. Ext., vol. 20, no. 1, pp. 1-13, 2013.

[9] T. K. Samant, "Bud chip method: A potential technology for sugarcane (Saccharum officinarum) cultivation," J. Med. Plants Stud., vol. 5, no. 3, pp. 355-357, 2017.

[10] A. Zainuddin and R. Wibowo, "Preferensi Petani terhadap Varietas Tebu di PT. Perkebunan Nusantara X," J. Pangan, vol. 28, no. 1, pp. 4556, 2019.

[11] A. Zainuddin and R. Wibowo, "Preferensi Risiko Produksi Petani Tebu Di Wilayah PT. Perkebunan Nusantara X," in Prosiding Seminar Nasional Hasil Penelitian Sosial Ekonomi Pertanian, 2018.

[12] I. Purnamasari, N. Hanani, and Suhartini, "Technical Efficiency Analysis of Sugar Cane Farming In East Java Indonesia (Statistical Approach of Frontier Production Functions)," Agric. Socio-Economics J., vol. 18, no. 1, pp. $23-$ 29, 2018.

[13] E. Mutenheri, D. Kibirige, M. B. Masuku, and A. - Singh, "Production Efficiency of smallholder Sugarcane Farmers in Swaziland: A Case Study of Ubombo (Lusip \& Poortzicht) Andhhohho (Kddp \& Vuvulane) Farmers," Int. J. Bus. Manag. Invent., vol. 6, no. 72-80, pp. $72-80,6 \mathrm{AD}$.

[14] J. Chen, "Utility Priority Number Evaluation for FMEA," J. Fail. Anal. Prev., vol. 7, no. 5, pp. 321-328, 2007.

[15] N. Xiao, H. Z. Huang, Y. Li, L. He, and T. Jin, "Multiple failure modes analysis and weighted risk priority number evaluation in FMEA," Eng. Fail. Anal., vol. 18, no. 4, pp. 1162-1170, 2011.

[16] J. Hallikas, I. Karvonen, U. Pulkkinen, V. M. Virolainen, and M. Tuominen, "Risk management processes in supplier networks," Int. J. Prod. Econ., vol. 90, no. 1, pp. 47-58, 2004.

[17] H. Aini, M. Syamsun, and A. Setiawan, "Risiko Rantai Pasok Kakao Di Indonesia Dengan Metode Analytic Network Process Dan Failure Mode Effect Analysis Terintegrasi,” J. Manaj. Agribisnis, vol. 11, no. 3, pp. 209-219, 2014.

[18] T. Roger and A. Engler, "Risk Preferences Estimation for Small Rasberry Producers in the Bio-Bio Region Chile," Chil. J. Agric. Res., vol. 68, no. 4, pp. 175-182, 2008. 
